\title{
The Economics of Housing the Homeless: What Causes the Problem and Why Haven't Federal Policies Helped?
}

\author{
By Sarah V. Ficenec
}

In the mid-1980s, homelessness increased in visibility across the United States, and interest rose as to the causes and possible solutions to the problem. Among others studying the issue, economists focused much of their attention on the central problem faced by the homeless - a lack of housing. Among the reasons economists cited for homelessness included a rise in housing prices, the filtering out of low-quality units in the housing market, increasing income inequality, and income shocks; these issues, combined with other factors that can make a person or family more susceptible to homelessness - such as substance abuse, mental illness, or social isolation - likely led to the increasing numbers of homeless in the 1980s. Looking at the causes of homelessness from an economic perspective also reinforces the reasons why many federal policies have been unable to solve or greatly decrease the problem in the past several decades. Since homelessness is still a concern across the country - especially in the wake of the recent recession - there continues to be a need to evaluate and find additional solutions to the problem.

\section{Introduction}

In the mid-1980s, there was a rising national consciousness about what appeared to be suddenly increasing numbers of homeless individuals on city streets. Where once these individuals had mostly confined themselves to specific neighbor- hoods and ventured into other areas only during the day, perhaps to solicit funds through panhandling, now the homeless were visible at all hours of the day and there seemed to be more of them. In addition, this increase occurred during the economic boom of the mid- to late-1980s, and the homeless continued to populate heavily trafficked city areas even through the prosperous 1990 os and 2000s.

During the two decades since the rise of a "new homelessness" in which more people either were or appeared to be homeless, there has been interest and examination by academics and practitioners into the causes and possible solutions to the problem of homelessness. Homelessness continues to be an important issue of social and economic concern to the country and a conspicuous problem for policymakers. As O'Flaherty (1996) notes when discussing the rise of homelessness in the mid-1980s:

The interesting question is not who is at the bottom of the housing list, but why the bottom of the housing distribution is on the street rather than ... where it was thirty years ago. Many of these same people are at the bottom of the clothing market too, but they aren't naked (4).

Homelessness remains an important challenge, especially as the nation struggles to recover from the recession and a burst housing bubble with constrained federal and local spending. 
After briefly reviewing who is homeless and the difficulty in determining that number, this paper will consider the various explanations - including a rise in housing prices, the filtering out of low-quality units in the housing market, increasing income inequality, income shocks, and the effects of other types of emergencies or long-term negative conditions - economics provides for the problem of homelessness as well as the reasons why various policy options are not solving this economic problem. ${ }^{1}$

\section{Defining "Homelessness" and "the Homeless"}

One of the primary difficulties in designing public policies to help the homeless is defining who, exactly, are "the homeless," and that differing definitions of homelessness may lead to confusion (O'Flaherty 1996). In the early part of the twentieth century, to be homeless was to lack an affiliation in society rather than to lack housing; as the century ended and the new homelessness rose, the defining characteristic of "official homelessness" came to be a lack of housing, although, as O'Flaherty (1996) observes, this definition took on a cyclical identity: "Where you slept last night determined whether you were homeless. But ... the sleeping places that qualified you as homeless were those where, it was thought, only vagrants slept" (10).

While academics and practitioners were classifying the homeless by where they slept at night and not by what they did during the day, much of the general public continues to perceive the problem of homelessness through their day-time encounters with those panhandling, washing windshields, collecting recyclables, or loitering in public areas. The general public would have no way of knowing where these people slept at night, so appearance and daytime activities characterize who might be homeless. While there may in truth be much overlap between these two groups, they may not contain the same individuals - some panhandlers or loiterers may have a home to sleep in at night, while those sleeping on the streets or in shelters may have a regular job during the day.

This discrepancy between official and general definitions of homelessness has led to conflicting approaches in how to resolve the problem and bring people in off the streets. It has also led to challenges simply in counting who is homeless. In 2001, Congress mandated that the US Department of Housing and Urban Development (HUD) assist local communities with developing methods to report on homeless clients served through various programs (Department of Veterans

Table 1: Counting The Homeless.

\begin{tabular}{|c|c|c|}
\hline Number & $\begin{array}{c}\text { Point-in-time } \\
\text { estimate } \\
\text { (January 2009) }\end{array}$ & $\begin{array}{c}\text { Annual estimate } \\
\text { (October 2008 - } \\
\text { September 2009) }\end{array}$ \\
\hline Sheltered individuals & $\mathbf{2 1 5 , 9 9 5}$ & $1,034,659$ \\
\hline Unsheltered individuals & 188,962 & - \\
\hline Sheltered family members & 187,313 & 535,447 \\
\hline Unsheltered family members & 50,797 & - \\
\hline
\end{tabular}

Note: Point-in-time estimates refer to those homeless on one night in January 2009, while annual estimate refers to all those utilizing homeless shelters during the time period identified.

Source: HUD Office of Community Planning and Development 2010. 
Table 2: Demographic Characteristics of Sheltered Homeless Persons in 2009 Compared to the 2008 US and Poverty Populations.

\begin{tabular}{|c|c|c|c|}
\hline Characteristic & $\begin{array}{l}\text { Percentage of } \\
\text { all sheltered } \\
\text { homeless } \\
\text { persons, } 2009\end{array}$ & $\begin{array}{c}\text { Percentage of } \\
\text { the } 2008 \text { US } \\
\text { poverty } \\
\text { population }\end{array}$ & $\begin{array}{c}\text { Percentage } \\
\text { of the } 2008 \\
\text { US } \\
\text { population }\end{array}$ \\
\hline \multicolumn{4}{|l|}{ Gender of adults } \\
\hline Male & $63.7 \%$ & $40.5 \%$ & $48.7 \%$ \\
\hline Female & $36.3 \%$ & $59.5 \%$ & $51.3 \%$ \\
\hline \multicolumn{4}{|l|}{ Ethnicity } \\
\hline $\begin{array}{l}\text { Non-Hispanic/ } \\
\text { non-Latino }\end{array}$ & $80.5 \%$ & $75.1 \%$ & $84.6 \%$ \\
\hline Hispanic/Latino & $19.5 \%$ & $24.9 \%$ & $15.4 \%$ \\
\hline \multicolumn{4}{|l|}{ Race } \\
\hline White, Non-Hispanic & $38.1 \%$ & $46.2 \%$ & $65.4 \%$ \\
\hline White, Hispanic & $11.6 \%$ & $15.0 \%$ & $9.6 \%$ \\
\hline $\begin{array}{c}\text { Black or African } \\
\text { American }\end{array}$ & $38.7 \%$ & $22.1 \%$ & $12.4 \%$ \\
\hline Other single race & $4.7 \%$ & $13.8 \%$ & $10.3 \%$ \\
\hline Multiple races & $7.0 \%$ & $2.9 \%$ & $2.3 \%$ \\
\hline \multicolumn{4}{|l|}{ Age } \\
\hline Under age 18 & $22.2 \%$ & $33.9 \%$ & $24.3 \%$ \\
\hline 18 to 30 & $22.3 \%$ & $23.8 \%$ & $18.2 \%$ \\
\hline 31 to 50 & $38.3 \%$ & $21.9 \%$ & $28.2 \%$ \\
\hline 51 to 61 & $14.4 \%$ & $9.2 \%$ & $13.9 \%$ \\
\hline 62 and over & $2.8 \%$ & $11.3 \%$ & $15.4 \%$ \\
\hline \multicolumn{4}{|l|}{ Household size } \\
\hline 1 person & $64.1 \%$ & $16.6 \%$ & $13.0 \%$ \\
\hline 2 people & $10.0 \%$ & $18.4 \%$ & $25.6 \%$ \\
\hline 3 people & $10.2 \%$ & $17.1 \%$ & $18.9 \%$ \\
\hline 4 people & $7.9 \%$ & $18.5 \%$ & $20.9 \%$ \\
\hline 5 or more people & $7.9 \%$ & $29.4 \%$ & $21.6 \%$ \\
\hline \multicolumn{4}{|l|}{ Special populations } \\
\hline Veteran (adults only) & $11.1 \%$ & $5.2 \%$ & $9.7 \%$ \\
\hline Disabled (adults only) & $37.8 \%$ & $26.2 \%$ & $15.5 \%$ \\
\hline
\end{tabular}

Source: HUD Office of Community Planning and Development 2010. 
Affairs and Housing and Urban Development, and Independent Agencies Appropriations Act 2001). HUD's annual pointin-time estimates of the homeless and one-year estimates of the sheltered homeless have become the generally-accepted count of the homeless population. The two methods produce different results of who is homeless in America because the pointin-time estimate attempts to count everyone who is homeless within 24 hours, no matter where they are located (e.g. in shelters or on the streets), while the one-year estimate only counts those in shelters. In addition, communities might use different counting methods, and some homeless individuals may try to be invisible to counters. As Table 1 shows, during the pointin-time estimate count in January 2009, over 643,000 people were found to be homeless, while over 1.5 million homeless Americans were sheltered during from October 2008 to September 2009.

Since the point-in-time estimates are observational, those conducting the effort can not detail exact characteristics of the homeless. Using the annual estimates of sheltered individuals, however, can provide a rough approximation of the characteristics of the homeless population in America. Table 2 reproduces HUD's comparison of the characteristics of the sheltered homeless population in 2009 to that of the poverty and general populations in the United States in 2008. As can be seen, men, African Americans, middle-age individuals (from 31 to 50 years old), veterans, and the disabled are overrepresented in the homeless population as compared to both the general population and those in poverty. In addition, most homeless are not in families but are solitary individuals, likely due to the fact that much of the structure of US homelessness assistance is geared toward families.

Especially when discussing policy options with regard to housing the homeless as well as preventing homelessness, it is important to distinguish between those who are homeless temporarily and those who are chronically homeless. Those who are only temporarily homeless may simply need short-term help to overcome an emergency such as job loss; according to HUD (2010), over a third of those seeking emergency shelter stay for less than a week. Meanwhile, those who are chronically homeless - which HUD defines as someone who has been homeless for over one year or who has been homeless at least four times in the past three years - tend to face more challenges in overcoming their housing situation and possible related problems such as health problems (including mental health issues), drug or alcohol abuse, and social isolation. The number of individuals classified as chronically homeless by HUD has decreased for the past several years, with most of this decline occurring among those who were previously unsheltered.

\section{The Economics of Homelessness}

Since the mid-1980s, there has been an effort among economists to find the economic determinants of homelessness. Most of these studies utilize the official identification of "homelessness" as those without a home, rather than looking at the daytime homeless that the general public perceives. This leads to a focus on whether the housing market is failing these individuals and, if so, how the problem can be corrected, whereas other disciplines may investigate other causes of homelessness (such as mental illness or discrimination) and, therefore, advocate for different solutions. Yet, even those who argue that housing is not the primary cause of homelessness are likely to focus some of their attention on policy options that would increase housing for the homeless, since, as Jencks (1994) argues, "If people have housing, the rest of their life may improve. Even if it does not, at least they have a home" (107). Determining a cause of homelessness has been a challenge, however, since the condition is likely the result of a confluence of factors. Determining how to address the problem 
of homelessness depends to a great degree on how the problem is defined.

\section{Housing Prices}

One of the key theories of an increase in homelessness since the mid1980 s concerns the rising cost of housing. In their study of housing affordability since 1960, Quigley and Raphael (2004) find that the poor and near-poor faced rents that increased more than that of median renters; from 1960 to 2000 , the percentage of income that poor renters devote to rent increased from 44 percent to 64 percent, compared to the pool of all renters, who saw an increase in the portion of their income going to rent increase from 19 to 26 percent. Further, the percentage of the poorest renters paying more than 30 percent of their income (which is the typical guideline for the percentage of income devoted to housing) for rent increased from 55 percent to 77 percent, while the percentage of all renters paying over 30 percent of their income for rent increased from 23 to 40 percent (Quigley and Raphael 2004).

Malpezzi and Green (1996) also note that there were drastic changes to the US housing market in the 1980 s, with lowincome households paying substantially greater proportions of their incomes for much better housing quality. They cite a number of possible explanations for this situation, including increased housing quality and utility costs amid decreased incomes or the disappearance of extremely low-cost housing, such as lodging houses and single room occupancy hotels that had been available to homeless in the past; if the lowest-quality housing options disappeared, people would be expected to pay more for the new lowest-quality options available. A popular policy option to counter the rise in housing prices and its perceived influence on the increasing number of homeless has been rent subsidies; however, although much of the homeless population would be eligible for such subsidies due to the lack of or low income or other conditions (such as a disability), they can have difficulty accessing such aid for a variety of reasons, as will be discussed below. That said, the simple fact that housing prices rose during the 1980 s is not by itself an adequate explanation of the rise of homelessness.

\section{Housing Quality and Filtering}

Much of the analysis of the relationship of housing price changes to homelessness focuses on housing quality and filtering of the market. The homeless (along with those with very low incomes) will typically consume very low-quality housing. Although the housing may be dilapidated or otherwise dangerous, it could also mean that the housing might be very small, without the amenities middle-class families are used to (such as full-size refrigerators or central heat), with insect or rodent infestations, or other problems.

This housing can either be produced directly, through new construction, or indirectly, through filtering. Due to the costs of construction, it is much more likely that very low-quality housing will be created through filtering, rather than construction. Filtering occurs because housing producers would rather spend the money to build nicer houses and apartments that can rent for more money, then let these units degrade over time as maintenance costs increase (Quigley and Raphael 2001). O'Flaherty (1996), who terms this relationship the "price-quality schedule," sums it up as "poor people get their housing as hand-me-downs from richer people - not the richest people, though, because the highest qualities of housing are maintained and not allowed to deteriorate" (103).

For O'Flaherty (1996), there are five necessary conditions that the pricequality schedule must fulfill in order to help explain homelessness:

1. The operating cost of the housing creates a minimum rent (or "floor") below which rents in the market for specific 
qualities cannot descend; if prices go below that level, the owner will abandon the property or find some other use for it, rather than continue renting it.

2. The rent for the lowest quality housing in the market must exactly equal operating cost.

3. Rents that can be collected as the housing deteriorates must match construction costs.

4. The quality at which housing deterioration starts depends on the value of the property, which relates to construction quality.

5. In a long-run equilibrium, the number of houses built must equal the number abandoned.

Deviations from these conditions in the short-term help explain dislocations in the housing market and resulting increase or decrease of homelessness as the market adjusts.

Just as for individuals with higher incomes, the homeless must make a choice between consuming housing and consuming all other goods, but the income level of the poor restricts the choices available (O'Flaherty 1996). Below a certain quality point, individuals would choose to live on the street rather than pay the marginal cost of the housing, which Quigley and Raphael (2001) define as:

Holding preferences constant, the richest, rational homeless person is just indifferent between consuming "abandonment-quality" housing at the market-determined rent, on the one hand, and homelessness at zero rent on the other hand. Homelessness in this model results from decisionmaking under extreme income constraints and not from a preference for the "homeless lifestyle." The Hobson's choice is between consumption of very low quality housing that absorbs a large portion of income, or increased consumption of other necessities with zero housing expenditures (329).
Therefore, according to this theory, there is not an affordable housing problem for the homeless - the homeless are simply making a rational choice to use their limited funds in a different way. ${ }^{2}$

\section{Income inequality}

Together with the price-quality schedule, growing income inequality starting in the 1980s also may have had an effect on increasing rates of homelessness by altering the number of households looking for housing at various qualities. First, as Mansur, Quigley, Raphael, and Smolensky (2002) note, those with higher incomes will demand more land for their housing, which decreases the supply of land and drives up its price and the price of the housing on it. Second, and more importantly, growing income inequality leads to a smaller middle class, which results in a smaller demand for housing at a middle quality and a larger demand for lowerquality housing (Mansur et al. 2002). O'Flaherty $(1995,1996)$ and Quigley and Raphael (2001) also argue that income inequality increased the number of homeless individuals, the latter noting that their regression analysis shows high rents, as compared to a person's income or assets, increases homelessness.

This demand for more low-quality housing does not decrease the stock of housing available at that quality, but increases the number of people competing for it. This affects the price-quality schedule, which results in a higher price for the lowest-quality housing available. Those who were previously living in housing that was just above the level of homelessness will now choose homelessness because the price of their housing will rise and not be as attractive, while the attractiveness of homeless has not changed.

\section{Regulations}

Other economic theories of homelessness argue that various regulations cause homelessness. For example, some argue that housing quality in the 
United States, which has risen since the early twentieth century due to increased regulations about housing size and facilities (such as indoor plumbing), has led to an increase in housing prices and thus in homelessness. Both Quigley and Raphael (2004) and Malpezzi and Green (1996) find that increasing regulation in a city increases rent for low-cost housing. O’Flaherty (1996), however, disagrees with this contention because, while regulations may have increased some operating costs of housing (e.g. installation of smoke detectors), they also may have decreased other costs (e.g. lowered rates for fire insurance), thus limiting the effects at the margins of housing prices. $\mathrm{He}$ also argues that the enforcement of regulations matters as much as the number of the regulations on the books. In his analysis of five cities, he finds very little linkage between their history of housing quality regulation and levels of homelessness.

\section{Land Use REgulations}

By limiting the supply of land available for development in a community, land use regulations have also been accused of contributing to homelessness within urban areas by pushing up prices of housing that can be built. However, it is difficult to determine the actual effect of land use regulations for a number of reasons, including endogeneity problems (wealthier communities may be more likely to impose such restrictions and also have higher prices for the lowest-quality housing available) as well as lack of enforcement (see Quigley and Rosenthal 2005). There would seem to be some effect of such restrictions on prices, but there is little study so far of the direct effect on homelessness. Most likely, land use regulations limit new construction, which encourages owners to maintain their property and decreases the quantities available for filtering, thereby increasing homelessness.

\section{Rent Control}

Housing quality and land use restrictions are not the only methods of regulation that may affect homelessness. Some people, especially those on the right politically, argue that rent control, or limits on the maximum rent that a landlord can charge a tenant, causes homelessness. Critics of this argument note that proponents model the relationship too simply, ignoring a wealth of variables that could also account for homelessness in various communities (see Quigley 1990). While O'Flaherty (1996) cannot find theoretical evidence to completely dispute the effect of rent control on homelessness, he does argue that there is an inverse relationship historically between rent control restrictions and the size of the homeless population.

There are also other effects of rent control on housing markets. Olsen (1972, 1997) finds that households in rent-controlled units consume less housing in exchange for other goods, while, in an analysis of the rental market in Los Angeles in late 1970s, Fallis and Smith $(1984,1997)$ observe that, while rent controls may actually lower the rent on controlled units (compared to forecasted rates), rents for uncontrolled units will be significantly higher than forecasted rates. This is largely due to those demanding but being unable to obtain controlled units spilling over into, and raising demand and therefore prices in, the uncontrolled market.

\section{Income Shocks}

There are a number of causes that can place a person or family at risk of being homeless, including low income, mental illness, substance abuse, chronic illness, and others. However, neither these vulnerabilities alone, nor combined with the state of the housing market, determine whether a household is homeless. Rather, there needs to be a shock that causes that household's equilibrium to shift so they can no longer afford the housing they currently have. Naturally, this shock often is 
related to income, and includes sudden unemployment, changes in welfare status, and, to a lesser degree, rent increases. O'Flaherty (2009) argues that incomes change much more than rents and that "renters in general and poor renters in particular do face noticeable rental market risk: even in relatively tranquil macroeconomic times, there is a 5-10 \% chance of being hit with a crushing rent increase" (14).

\section{Other Causes}

Much of the literature outside the field of economics details the many factors that can lead to homelessness or make a person more susceptible to the condition. Jencks (2004) notes that:

Any given individual's chances of being homeless obviously fall on a continuum that runs from very high to very low. If you have no salable skills, no claim to government benefits, no friends or relatives willing to help out, and spend whatever money you have on crack, you are likely to become homeless. If you have skills that employers value, unemployment compensation when you lose your job, an extended family with a commitment to helping one another, and a strong aversion to drugs and alcohol, your chances of ending up homeless are negligible (49-50).

However, there is more agreement on certain likely causes of homelessness than on others. For example, there is consensus that mental illness or drug or alcohol abuse can increase one's probability of becoming homeless (although, of course, not all mentally ill individuals or substance abusers become homeless). Early (2005), for example, finds that the likelihood of being homeless increases in families with children or if the head of the household abused alcohol or drugs. But especially when discussing the rise of "new homelessness," there are conflicting accounts of whether deinstitutionalization of the mentally ill or the crack epidemic increased homelessness. Jencks (1994), for one, argues that these factors did increase the number of people who were homeless in the 1980s, while Quigley, Raphael, and Smolensky (2001) argue that deinstitutionalization and crack usage may not have played a large role. What is commonly agreed, though, is that there are additional factors besides the housing market that make one more susceptible to becoming homeless.

\section{Policies Directly Addressing Homelessness}

In response to the rise in homelessness in the 1980s, Congress passed the McKinney-Vento Homeless Assistance Act in 1987, which brought together all programs across the federal government that served the homeless in an attempt to better address the myriad causes of the problem. Among other things, the act: created an Interagency Council on the Homeless; authorized the Emergency Food and Shelter Program administered by the Federal Emergency Management Agency as well as other programs administered by HUD, the Department of Labor, and the Department of Health and Human Services; and expanded the Food Stamp Program to aid homeless participation (HUD 2007). In the years since the original act, Congress has renewed it and expanded the funded services.

Public responses to homelessness, too, focus on efforts to directly combat homelessness and provide more funds to get people off the streets and into some type of shelter. However, only providing shelter for the homeless is often not enough to end, or even limit, homelessness, which has helped spur the movement toward programs that place the homeless in temporary or permanent homes, where they can receive help to deal with problems in addition to not having shelter. Homelessness prevention programs, however, have not been as successful, primarily due to the difficulty of identifying those who truly would be homeless without the services. 
Public Shelters

In its homelessness assessment, HUD (2010) found that, in 2009, there were 6,009 emergency shelters nationally, providing 214,425 beds year-round for the homeless, an increase from the previous year. Many people calling for help for the homeless advocate first for more and better public shelters, so that these individuals do not have to spend their nights on the street.

Economists, however, are unenthusiastic about using shelters to confront the problem of homelessness, because shelters have one fundamental flaw: if shelters are nice enough to entice people into them off the streets and without substantial restrictions on a resident's freedoms (otherwise the homeless will choose to stay on the streets), more people might rationally choose to be in shelters rather than paying for the lowest-quality housing available (since they would be able to keep the money they would have paid for housing and use it on other items) and, therefore, join the ranks of the homeless. O'Flaherty (1996) also notes that "better shelters could have an income effect residents could feel more contented and not look for more money - and a substitution effect - shelter rules could make it difficult to panhandle at clubs or collect cans at night" (94). It should also be noted that public shelters should not be taken as an indicator of the level of homelessness in a city, but rather a measure of generosity among individuals and taxpayers (O’Flaherty 1996).

\section{Continuum of Care and Housing Readiness}

Temporary bed-only shelters are, of course, a quick response to homelessness, but they are not the best response for a number of reasons. In addition to possibly increasing the number of homeless (as noted above), they do not help the homeless deal with the myriad other problems they are potentially facing, including unor underemployment, substance abuse, mental illness or other challenges. They are also not a long-term solution to the problem.

For much of the past 20 years, homelessness policies (including but beyond shelters) operated through the Continuums of Care (COC), which focused on "housing readiness," or resolving problems thought to have contributed to homelessness before moving the homeless household from a shelter to transitional then permanent housing (Cunningham 2009). COCs operate at the local level with federal funding as a network of providers of services to the homeless. According to HUD (2010), in 2009 there were 7,229 transitional housing programs with 207,589 beds, increases from the previous year. However, Cunningham (2009) found that housing readiness programs do not help most people make the transition from homelessness; only 28 percent of those who pass through the program end up in permanent housing without a subsidy, while 16 percent remain on the streets.

\section{Supportive Housing}

The lack of dramatic success in housing readiness programs led to a new solution that has become more prevalent - supportive housing - through which homeless individuals are moved directly into permanent housing and then receive help to tackle other problems facing them, such as mental illness, substance abuse, and unemployment. Supportive housing has a number of names, operates through various federal, local, and nonprofit programs, and is most beneficial when made available to the chronically homeless. According to HUD (2010), there were 6,701 permanent supportive housing programs with 219,381 year-round beds available in 2009. In the last decade, Congress committed to increasing the number of permanent supportive housing units substantially.

While these programs may seem at the outset more expensive than other options, factoring in the other services 
provided to homeless populations - such as emergency room use and jail time lowers their relative costs (Cunningham 2009). A number of these programs operate across the country and provide some evidence concerning the expenses of various methods of housing the homeless. In Washington, DC, the permanent supportive housing program had a total of 2,320 units (or around 2,741 beds) in the third quarter of 2008, and each cost, on average, about $\$ 8,500$ annually. Only about half of program participants were known to be chronically homeless (Burt and Hall 2009). ${ }^{3}$ Another example and one of the first such nonprofit programs, the Corporation for Supportive Housing (CSH), was founded in 1991 in New York City and served homeless single adults who also suffered from health problems including AIDS, mental illness, and substance abuse; today, it is active in 15 states, operates with some federal funds, and serves families as well as single individuals. A report by the Robert Wood Johnson Foundation, one of CSH's funders, identifies the cost-effectiveness of supportive housing in Los Angeles - a single day of CSH costs $\$ 30$, while a day at a shelter costs $\$ 37.50$ and a day of incarceration costs $\$ 85$ (Core, Pollak, and Stein 2006). ${ }^{4}$ In addition, Poulin, Maguire, Metraux, and Culhane (2010) found that, on average, a chronically homeless individual in Philadelphia used $\$ 7,455$ annually in public services, with almost 50 percent of the funds spent split almost evenly between shelter housing (at $\$ 28$ per day) and incarceration (at $\$ 76$ per day).

\section{Homelessness Prevention \\ Many efforts also focus on assist-} ing those who are susceptible to homelessness, so they are able to remain in their current home or quickly find new housing. Such services include rental assistance, housing search help, utility payments, and other activities, and $\$ 1.5$ billion was included in the American Recovery and Reinvestment Act of 2009 for homeless- ness prevention until September 30, 2011. However, while preventing homelessness is a worthwhile goal, the risk factors that may lead to homelessness are complex; homelessness prevention may mean providing funding to individuals who never would have ended up in homelessness, while possibly not providing funding to people who may become homeless but fall under the radar. Further, it is the confluence of both personal characteristics and housing market characteristics that lead to homelessness, and so funding needs to be provided to help populations vulnerable to both (see Burt 2001; Elliott and Krivo 1991; O’Flaherty 2004).

\section{Can Housing Policies for the Low-Income Help the Homeless?}

Despite the popular focus on policies specifically serving the homeless, the homeless are also served by a wide variety of policies designed for the low-income, the definition of which varies by government agency and program. These latter programs, which are not specifically for the homeless but can be accessed by them, are known as "mainstream programs." In a 2008 report, the US Interagency Council on Homelessness found that there were 75 programs serving homeless families with children, but only 15 of these were targeted at the homeless while the rest were mainstream programs. This is similar to results compiled by the US Government Accountability Office (GAO) (2000) eight years earlier, which found that eight agencies offered 50 programs with services available to the homeless, with over two-thirds of these programs intended for the general low-income population, rather than being available only to the homeless.

There are significant problems with the homeless utilizing housing programs designed for the low-income, however, due both to barriers faced as a condition of homelessness and to design of the programs: as the GAO (2000) study observes, the conditions of homelessness include "transience, instability, and 
a lack of basic resources" while "federal programs do not always include service providers with expertise or experience in addressing the needs of homeless people" and the "federal government's system for providing assistance to low-income people is highly fragmented" (4). In addition to the practical challenges of the homeless accessing programs for the low-income as well as the scarcity of these resources, there are other problems with mainstream programs that result directly from the economics of homelessness.

Perhaps the biggest problem for the homeless in accessing "affordable housing" programs, whether they are tenant- or place-based programs, are the income hurdles that the household must confront, simply put, in many cases a homeless individual or family will be hardpressed to find the money necessary for a security deposit or to pay a month's rent at the beginning of the month. Even with rent limits based on income, it may be impossible for a homeless household to have that much money available at one time; this explains one reason why individuals or families, after losing an apartment or house, may move first to a hotel or motel - despite the higher per night expense (especially when these facilities lack a kitchen), the fact that the owners need to be paid only daily or weekly would ease payment. However, if that burden is overcome (and there are programs available to help the homeless or potentially homeless pay a security deposit or first month's rent), there are a number of other programs for the low-income that could, in theory, assist the homeless.

\section{Subsidized Housing}

There are a number of programs that offer subsidized housing to low-income families, including tenant-based programs - in which the benefit is attached to the individual, who can use the subsidy in various locations provided the locations meet set standards - and placebased programs - which are connected to housing units that people can access. Both theoretically and empirically, there is some support for subsidized housing as a tool to combat homelessness. O’Flaherty (1995), for example, supports voucher programs for the homeless, noting that, even if subsidies do not go to the homeless but rather those with higher - although still low incomes, vouchers shift these individuals to higher housing qualities, making the lowest housing quality levels available to those with even lower incomes, although in a later work (1996) he also notes that this is a long-run condition so that, in the short-run, "the effect is probably the opposite: with a fixed stock of housing, if one group consumes more, the other group has to consume less" (200).

There have been a number of policy simulations concerning subsidized housing and the homeless or low-income. Ohls (1975, 1997) supports O'Flaherty's (1995) conclusions about filtering in the housing market by comparing the effects of a voucher program that utilizes existing construction versus a program that constructs housing specifically for the low-income. In this study, those receiving the vouchers can increase the quality of housing they consume, which encourages construction at even higher levels of quality that would then filter down to voucherholders, and also encourages maintenance on existing low quality housing that can be consumed with vouchers; this increased filtering also would trickle down to the low-income and homeless who did not have vouchers. New construction, however, has mixed results in that it removes some of the poor population from the existing housing market, which increases the lowest quality available on the market; this helps the very low income, because prices for the lowest quality housing decrease due to decreased demand, but those with slightly higher incomes are hurt as prices for slightly better housing are increased.

Mansur et al. (2002) examines the effect on the homeless population in four cities of either a voucher program that 
equals the difference between the rent on a low-quality unit and 30 of percent an individual's income or general maintenance subsidies (to all landlords or just those supplying low-quality housing). They find that the largest percentage decreases in the homeless population would result from the demand-side voucher program, although rents do rise slightly with the program. Both of the maintenance subsidy programs result in substantial decreases of homelessness as well as of rent on lowquality units. They further determine that, while the total benefits are greatest under the general maintenance subsidy program, low-income consumers benefit much more with vouchers.

Due to the limited availability of such programs, however, some express doubts about their usefulness for decreasing homelessness. As Early (1998) notes, "the claim that subsidized housing is an important tool in the fight against homelessness is based on the assumption that these units are being occupied by households with a high risk of being homeless" (688). However, in a logit regression analysis he finds that most of those in subsidized housing are not, in fact, at risk of being homeless; he therefore argues that the poor targeting of these programs limits their effectiveness within current housing program budgets. Directing this assistance to those most in need (whether that be those already homeless with no other assistance or those most likely to become homeless) might serve to increase the effectiveness of rental subsidies. Such prioritization, however, may face political challenges, especially as local housing programs continue to face long waiting lists of those seeking assistance.

\section{Public Housing}

Large-scale public housing, which has largely fallen out of favor in the United States, faces a number of problems that make it the least preferable option for housing the homeless. A first challenge is similar to that faced by public shelters - if the quality is high enough and the prices low enough to encourage people to utilize it, it would likely house people who could afford other housing but choose to conserve their housing resources in order to have more funds available for other uses. Public housing is also unattractive as a solution to homelessness due to the large capital costs required to build and operate the units. O'Flaherty (1996) cites studies that show that individuals in public housing would only be willing to pay one dollar for every two dollars in benefits that are actually provided. The efficiency loss in this situation argues for policies that would provide better return for the tax dollars invested.

Further, this type of housing suffered administratively from a serious flaw in that, in some cases, the public housing authorities (PHA) received their subsidies from the federal government for the number of units they managed, not the number of people they housed. Poorer and larger families required more resources to be spent on their behalf by the PHAs but, since residents' rents were based on income, they paid less compared to better-off families. When PHAs could exercise their choice, therefore, they often preferred tenants with higher incomes so there was more funding available to operate the housing. With lower total income per unit, public housing quality decreased further and became preferable only for those with even lower incomes. This began a cycle that, eventually, led to a preference for vacancy and abandonment once marginal costs exceeded rents that could be collected (see O'Flaherty 1996).

For these reasons as well as others associated with the consequences of concentrated poverty (such as increased violence), large-scale public housing is no longer the preferred method for housing the homeless (as well as others with low incomes). Much of the focus today is on mixed-income developments, in which some units are reserved for those with low or no incomes while others are rented or 
sold at market prices.

\section{Conclusion}

Homelessness is now defined by academics and practitioners primarily as a personal lack of housing, with a specific focus on where a person slept the night before. This differs from some of the general public's concerns about the apparently homeless people they see during the daytime, which therefore can lead to policy differences when proposing solutions for the issue.

The rise in homelessness in the mid-1980s led to a new focus on the economic determinants of homelessness and, specifically, whether the housing market was functioning properly - if the market was working correctly, why were there increasing numbers of homeless? Most economists working on the issue came to the conclusion that, through the process of filtering in the housing market, people who could only afford the lowest quality of housing available were sometimes "choosing" homelessness in order to direct their limited funds to other consumption, rather than only purchasing such low-quality housing. Much of the increase in homelessness is also attributed to the increased income inequality of the era, which led to more demand for the lowest-quality housing, pushing up prices and causing more people to be unwilling or unable to pay for the low quality of housing available to them and, therefore, becoming homeless. There is still disagreement, however, over whether regulations on housing quality, land use, and rent control also had some effect on the number of homeless by decreasing the supply of low-quality housing available.

There have been a number of efforts to help the homeless find housing. In response to the rise of homelessness in the 1980 , there was a push to unify services provided directly to the homeless. Since then, the traditional methods of serving the homeless through emergency shelters and Continuums of Care or housing readiness programs have been replaced with supportive housing programs that provide shelter for the homeless and then help them resolve the other issues that may have led to that condition. Congress has also provided additional funding for homelessness prevention, although it can be difficult to determine which at-risk individuals and families will ultimately become homeless.

Many of the programs that the government offers to help fight homelessness are actually policies directed at the low-income, not just those without homes. The homeless face substantial problems in accessing these programs, including the effect of the conditions of homelessness on their ability to participate in the programs, the scarcity of the programs' resources, and the difficulty in securing money needed to pay non-funded housing costs; however, subsidized housing programs do show potential benefits for the homeless, through both greater filtering of the housing market as well as by providing direct access to the less expensive housing. Large-scale public housing, on the other hand, is largely inefficient in serving homeless populations.

Homelessness is not a problem that will ever disappear from the policy agenda without subsidization of housing for all; in a country that values free capacities at all levels. The challenge for policy makers is finding ways to help those who want housing but are unable to procure it or need short-term assistance to retain it. This problem will likely take on a new dimension in the coming years, as more people lose their homes due to the current housing crisis. Many of those who face foreclosure will not become homeless, but some will be vulnerable to ending up on the streets or in shelters. Especially at risk are those with low incomes who are renting homes that fall into foreclosures - they may not have the funds available to find new housing immediately. Finding ways to help those who become homeless will continue to be a challenge in the future, at both the federal and the local level. 


\section{References}

American Recovery and Reinvestment Act of 2009, Pub. L. No. 111-5, 123 Stat. 115 (2009).

Burt, Martha. 2009. "What Will it Take to End Homelessness?” Urban Institute, 2001. PolicyFile.

Burt, Martha, and Sam Hall. "Permanent Supportive Housing in the District of Columbia: Taking Stock and Looking Forward.” Urban Institute. PolicyFile.

Core, Susan, Lindsey Pollak, and Anne Stein. 2006. "More Than a Place to Live.” Robert Wood Johnson Foundation. PolicyFile.

Cunningham, Mary. 2009. "Preventing and Ending Homelessness - Next Steps." Washington, DC Urban Institute. http://www.urban.org/url.cfm?ID=411837.

Department of Veterans Affairs and Housing and Urban Development, and Independent Agencies Appropriations Act of 2001, Pub. L. No. 106-377, 114 Stat, 1441 (2001).

Early, Dirk W. 2005. "The Role of Subsidized Housing in Reducing Homelessness: An Empirical Investigation Using Micro-data.” Journal of Policy Analysis and Management 17 (1998): 687-696.

---. “An Empirical Investigation of the Determinants of Street Homelessness.” Journal of Housing Economics 14: 27-47.

Elliott, Marta, and Lauren J. Krivo. 1991. "Structural Determinants of Homelessness in the United States." Social Problems 38: 113-131.

Fallis, George, and Lawrence B. Smith. 1997. "Uncontrolled Prices in a Controlled Market: The Case of Rent Controls.” In Vol. 2 of The Economics of Housing, edited by John M. Quigley, 139-146. Cheltenham, UK: E. Elgar Pub. Originally published in American Economic Review (74 (1984)).

Jencks, Christopher. 1994. The Homeless. Cambridge, MA: Harvard University Press.

Malpezzi, Stephen, and Richard K. Green. 1996. "What Has Happened to the Bottom of the U.S. Housing Market?” Urban Studies 33: 1807-1820.

Mansur, Erin T., John M. Quigley, Stephen Raphael, and Eugene Smolensky. 2002. "Examining Policies to Reduce Homelessness Using a General Equilibrium Model of the Housing Market.” Journal of Urban Economics 52: 316-340.

O’Flaherty, Brendan. 1995. "An Economic Theory of Homelessness and Housing." Journal of Housing Economics 4: 13-49.

---. 1996. Making room: The Economics of Homelessness. Cambridge, MA: HarvardUniversity Press.

---. 2009. "What Shocks Precipitate Homelessness?” Discussion paper no. 0809-14. New York, NY: Columbia University.

---. 2004. "Wrong Person and Wrong Place: For Homelessness, the Conjunction is What Matters.” Journal of Housing Economics 13: 1-15.

Ohls, James C. 1997. "Public Policy Toward Low Income Housing and Filtering in Housing Markets." In Vol. 2 of The Economics of Housing, edited by John M. Quigley, 226-252. Cheltenham, UK: E. Elgar Pub. Originally published in Journal of Political Economy (2 (1975)).

Olsen, Edgar O. 1997. “An Econometric Analysis of Rent Control.” In Vol. 2 of The Economics of Housing, edited by John M. Quigley, 226-252. Cheltenham, UK: E. Elgar Pub. Originally published in Journal of Political Economy (80 (1972)).

Poulin, Stephen R., Marcella Maguire, Stephen Metraux, and Dennis P. Culhane. 2010. "Service Use and Costs for Persons Experiencing Chronic Homelessness in Philadelphia: A Population-Based Survey.” Psychiatric Services 61: 1093-1098. 
Quigley, John M. 1990. "Does Rent Control Cause Homelessness? Taking the Claim Seriously." Journal of Policy Analysis and Management 9: 89-93.

---. 2004. "Is Housing Unaffordable? Why Isn't it More Affordable?" Journal of Economic Perspectives 18: 191-214.

Quigley, John M., and Steven Raphael. 2001. "The Economics of Homeless: The Evidence from North America.” European Journal of Housing Policy 1: 323-336.

Quigley, John M., and Larry A. Rosenthal. 2005. "The Effects of Land Use Regulation on the Price of Housing: What Do We Know? What Can We Learn?” Cityscape: A Journal of Policy Development and Research 8: 69-137.

Quigley, John M., and Eugene Smolensky. 2001. "Homeless in America, Homeless in California." The Review of Economics and Statistics 83: 37-51.

US Department of Housing and Urban Development Office of Community Planning and Development. 2008. "The 2009 Annual Homeless Assessment Report.” Accessed February 13, 2011. http://www.huduser.org/Publications/pdf/2009_ homeless_508.pdf.

---. 2007. “McKinney-Vento Act.” Accessed April 12, 2010. http://www.hud.gov/offices/ cpd/homeless/lawsandregs/mckv.cfm.

US Government Accountability Office. 2000. "Homelessness: Barriers to Using Mainstream Programs.” Accessed March 25, 2010. http://www.gao.gov/new.items/ rc00184.pdf.

US Interagency Council on Homelessness. 2008. "Inventory of Federal Programs That May Assist Homeless Families with Children.” Accessed May 7, 2010. http:// www.usich.gov/library/publications/FamilyInventory_Mar20o8.pdf. 


\section{Notes}

1. Even as homelessness has been defined as a lack of housing, there has been debate about whether this is due more to issues of income, health concerns, or social isolation rather than housing market functions. Since much of the economics of homelessness is concerned with the housing market, this paper will only consider policies primarily concerned with making housing available to the homeless and not income maintenance or other programs.

2. One question that has arisen in the literature is whether mentally ill homeless individuals can actually make a "rational choice" on housing. However, this is a problem in general economic theory as well, even though the homeless experience higher rates of mental illness than the general public.

3. The status of the other participants, outside of being homeless, could not be determined.

4. Unfortunately, the success rates for either the District's program or CSH were unavailable.

Sarah V. Ficenec, a second year PhD student at the Trachtenberg School of Public Policy and Public Administration, is specializing in urban and social policy and currently works as a research assistant at The George Washington Institute of Public Policy. Sarah most recently worked as Associate Director for Policy and Communications at the Center for the Study of the Presidency and Congress and remains affiliated with the Center as a senior fellow for urban policy and a mentor in its Presidential Fellows Program. She has a Masters in Public Policy from the Johns Hopkins University and a BA in economics and history from Creighton University.

The author would like to thank Professors Joseph Cordes and Steve Redburn for their comments on early drafts of this paper. She would also like to thank Sarah Trumble, Whitney King, Andrea Leung, and Kaitlin Welborn for their editing work on multiple drafts of this paper. 